\title{
TOXIN GENOTYPES OF Clostridium perfringens IN ANIMAL FEED AND THEIR ROLE IN THE ETHIOLOGY OF ENTEROTOXEMIA IN DOMESTIC ANIMALS
}

\author{
Dubravka S. Milanov*1, Tamaš R. Petrović ${ }^{*}$, Dalibor S. Todorović ${ }^{1}$, \\ Nevenka R. Aleksić ${ }^{2}$, Ivana S. Čabarkapa ${ }^{3}$ \\ ${ }^{1}$ Scientific Veterinary Institute „Novi Sad“, 21000 Novi Sad, Rumenački put 20, Serbia \\ ${ }^{2}$ University of Belgrade, Faculty of Veterinary Medicine, 11000 Belgrade, Bulevar oslobođenja 18, \\ Serbia \\ ${ }^{3}$ University of Novi Sad, Institute of Food Technology, 21000 Novi Sad, Bulevar cara Lazara 1, Serbia
}

${ }^{*}$ Corresponding author

Tel.: +381214895346

E-mail: dubravka@niv.ns.ac.rs

\begin{abstract}
Clostridium perfringens is a Gram-positive, endospore-forming, anaerobic rod, ubiquitous in nature. C. perfringens strains can produce about 17 toxins. Many of them can lead to miscellaneous diseases, among which the enteric ailment may be the most common and is of utmost importance. In the present work 34 strains of $C$. perfringens isolated from feed and one from a cow suspected to have died of clostridial infection were subjected to molecular analysis. In order to detect the genotypes, the following genes coding for toxins were targetted: $c p a, c p b, c p b 2$, cpe, etx and iap. The multiplex PCR assay revealed that all $C$. perfringens isolates from animal feed were of type $A$ and $\beta 2$-toxinogenic type A strains, possessing only the cpa $(n=21)$, or both the cpa and the cpb2 genes $(n=13)$. The importance of $C$. perfringens toxins $\alpha$ and $\beta-2$ in the pathogenesis of enterotoxemia is discussed and the regulation on the detection of this bacteria in animal feed questioned. The use of PCR in practise could enable the toxin-genotyping of $C$. perfringens isolates and, thus, provide a real basis for the establishment of maximum acceptable limits of this bacteria in feed.
\end{abstract}

Key words: Clostridium perfringens, toxin genotyping, animal feed, multiplex PCR assay, cpa gen, cpb2 gen

\section{INTRODUCTION}

Clostridium perfringens is a Gram-positive, non-motile, endospore-forming, anaerobic (relatively oxygen-tolerant) bacteria, ubiquitous in nature (found in soil, dust, sewage, and fresh and marine water) and a common inhabitant of the intestinal tract in both humans and homeothermic animals (Songer, 1996; Brynestad and Granum, 2002). The species represents a very heterogeneous group with respect to metabolic bioproducts, toxins and pathogenicity. C. perfringens strains can pro- duce about 17 toxins (Uzal et al., 2015; Freedman et al., 2016), four of which ( $\alpha, \beta$, $\varepsilon$ and I) are major factors of virulence. Based on the capability to produce them, $C$. perfringens is classified into five toxotypes: A, B, C, D and E (Hatheway, 1990; Sawires and Songer, 2006). Two other major toxins are enterotoxin (CPE) and $\beta-2$ toxin, both possibly produced by all types of C. perfringens (Ata et al., 2013). Each toxotype may cause different diseases in animals, including acute enteritis and fatal 
enterotoxemia (Baums et al., 2004; Ata et al., 2013; Lyhs et al., 2013). Some varieties within types $A, B$ and $C$ produce certain combinations of antigens or toxins associated with defined diseases or syndromes (Ata et al., 2013; Uzal et al., 2010, 2014). Their quantities vary greatly between individual strains (Niilo, 1980).

C. perfringens may enter feed via contaminated raw ingredients, or by secondary contamination during processing, storage and dispersal of final products. Feed contamination depends on its composition, the hygiene during production and the storage conditions, and is directly proportional to the levels of soil and faecal contamination (Wojdat et al., 2006).

In the Republic of Serbia, in compliance with regulations (Regulations on the quality of animal feed), feed samples of 50 $g$ must not contain any $C$. perfringens. For food it is stated in The EFSA Journal (EFSA, 2005) that "C. perfringens is commonly present in foods and ingredients, occasionally at hundreds per gram, and microbiological testing for $C$. perfringens has limited value in ensuring food safety, because the organism is so common in or on foods that a positive result means little, unless very high numbers are present". In spite of being notorious for extremely toxigenic potential, not all of $C$. perfringens strains are capable of producing illness in neither animals nor humans.

Experimental researh has confirmed that the ingestion of $C$. perfringens will not lead to sickness per se, because the majority of bacteria consumed with food are destroyed by hydrochloric acid in the stomach. Moreover, C. perfringens does not exhibit adherence and invasive properties towards healthy intestinal mucosa. The development of subclinical or clinical clostridiosis in domestic animals always results from complicated interactions between the virulence of the bacteria (which is highly variable within this species), immune status of the host and the influence of a variety of non-specific factors associated with the farm management.

Gut microbiota disturbances (most frequently resulting from antibiotic therapy), management-related stress, sudden chan- ges in diet, and overeating and/or voraciousness, especially on high-protein and energy-rich foods, are predisposing factors for the development of enteritis and enetrotoxemia (Collier et al., 2008; Timbermont et al., 2011; Uzal et al., 2015).

For all these reasons, without the identification of toxin genotypes and the levels of feed contamination it is difficult to assess the health risk $C$. perfringens in feed poses to animals. Nonetheless, toxin genotyping of $C$. perfringens strains isolated from food stuffs and animal feed is not part of routine laboratory practice in Serbia.

In this work $C$. perfringens isolates $(n=34)$ from food intended for animals were subjected to multiplex PCR essay in order to detect genes: cpa ( $\alpha$ toxin), cpb ( $\beta$ ), cpb2 ( $\beta 2)$, etx $(\varepsilon)$, iap (1) and cpe (enterotoxin). Further, the importance of those findings are discussed from the standpoint of health risk to food-producing animals and, indirectly, to humans, consumers of animal products. The results of such investigations can be the basis for risk assessment and determination of critical limits of the presence of $C$. perfringens in animal feed.

\section{MATERIALS AND METHODS}

C. perfringens isolates. C. perfringens was isolated from feed samples according to the standard SRPS ISO 7937:2010. The species identification was based on: (1) the characteristics of the colonies grown on agar with the addition of $5 \%$ sheep blood and incubated in anaerobic conditions (GasPak EZ, Becton Dickinson and

Company, USA), (2) synergistic haemolysis with Streptococcus agalactiae (reverse CAMP test), and (3) biochemical properties: catalase test (negative), fermentation of glucose and lactose and production of lecithinase. Thirty-four isolates of $C$. perfringens were subjects of genotyping. Their origin is presented in Table 2. In addition, one isolate from the organs of a cow which was suspected to have died of enterotoxemia was assessed: the organs were sent to the laboratory with the feed that was allegedly the source of the infection. 


\section{DNA extraction and PCR amplification}

From C. perfringens isolates incubated overnight on blood agar suspensions in PBS were made and turbidity adjusted to 3.5 McFarland. One milliliter was transferred to an Eppendorf tube and boiled in water for 15 minutes. The tubes were cooled on ice and centrifuged for $8 \mathrm{~min}$ at $11,000 \times \mathrm{g}$. The supernatant obtained $(100$ $\mu \mathrm{L})$ was preserved in a freezer at $-20^{\circ} \mathrm{C}$ until being processed further. The multiplex PCR assay (mPCR) was performed according to the protocol described by Baums et al. (2004). Six sets of oligonucleotide primers were used (Table 1). The MPCR method was carried out using the "HotStar Taq Master Mix Kit" (Qiagen, Hilden, Germany), with small modification of manufacturer's instructions. Briefly, the amplification reaction was carried out in a volume of $25 \mu \mathrm{l}$ containing $3 \mu \mathrm{l}$ of DNA sample, $12.5 \mu \mathrm{l}$ of master mix and $25 \mathrm{pmol}$ of each primer. C. perfringens ATCC 13124 was used as the positive and $C$. sporogenes ATCC 19404 as the negative control.

The cycling conditions (Thermocycler Gradient, Eppendorf, Germany) were the following: initial denaturation at $95^{\circ} \mathrm{C}$ for 2 min 30s, 40 cycles of $1 \mathrm{~min}$ at $95^{\circ} \mathrm{C}, 1 \mathrm{~min}$ at $55{ }^{\circ} \mathrm{C}$ and $1 \mathrm{~min}$ at $72{ }^{\circ} \mathrm{C}$, which was followed by the final extension for $10 \mathrm{~min}$ at $72{ }^{\circ} \mathrm{C}$. Ten microlitres of the PCR products were separated by electrophoresis on a $1.5 \%$ agarose gel, stained with ethidium bromide $(0.25 \mathrm{~g} / \mathrm{ml})$ and documented with a gel documentation system (GelDoc-It ${ }^{2}$ Imager, UVP, Cambridge, UK).

\section{RESULTS}

All of the $C$. perfringens isolates formed small translucent colonies surrounded by the zone of double haemolysis on blood agar (Figure 1A). Clear zone of haemolysis results from the theta $(\theta)$ toxin, whilst the $\alpha$-toxin is responsible for incomplete haemolysis. The production of $\alpha$-toxin in all isolates was confirmed with the positive reverse CAMP test (Figure 1B).

The multiplex PCR assay revealed the presence of specific amplicons: 900-bp long, which are characteristic of cpa gene, $396 \mathrm{bp}$ of etx, and $200 \mathrm{bp}$ of the cpb2 gene encoding for $C$. perfringens toxins (Figures 2, 3 and Table 2). All C. perfringens isolates derived from feed were identified as type $A$ and $\beta 2$-toxinogenic type A strains, since they possessed only the cpa $(n=21)$, or the cpa and the $c p b 2$ genes $(n=13)$. In neither isolate from feed genes coding for beta $(c p b)$, epsilon (etx) and iota toxin (iap) were detected.

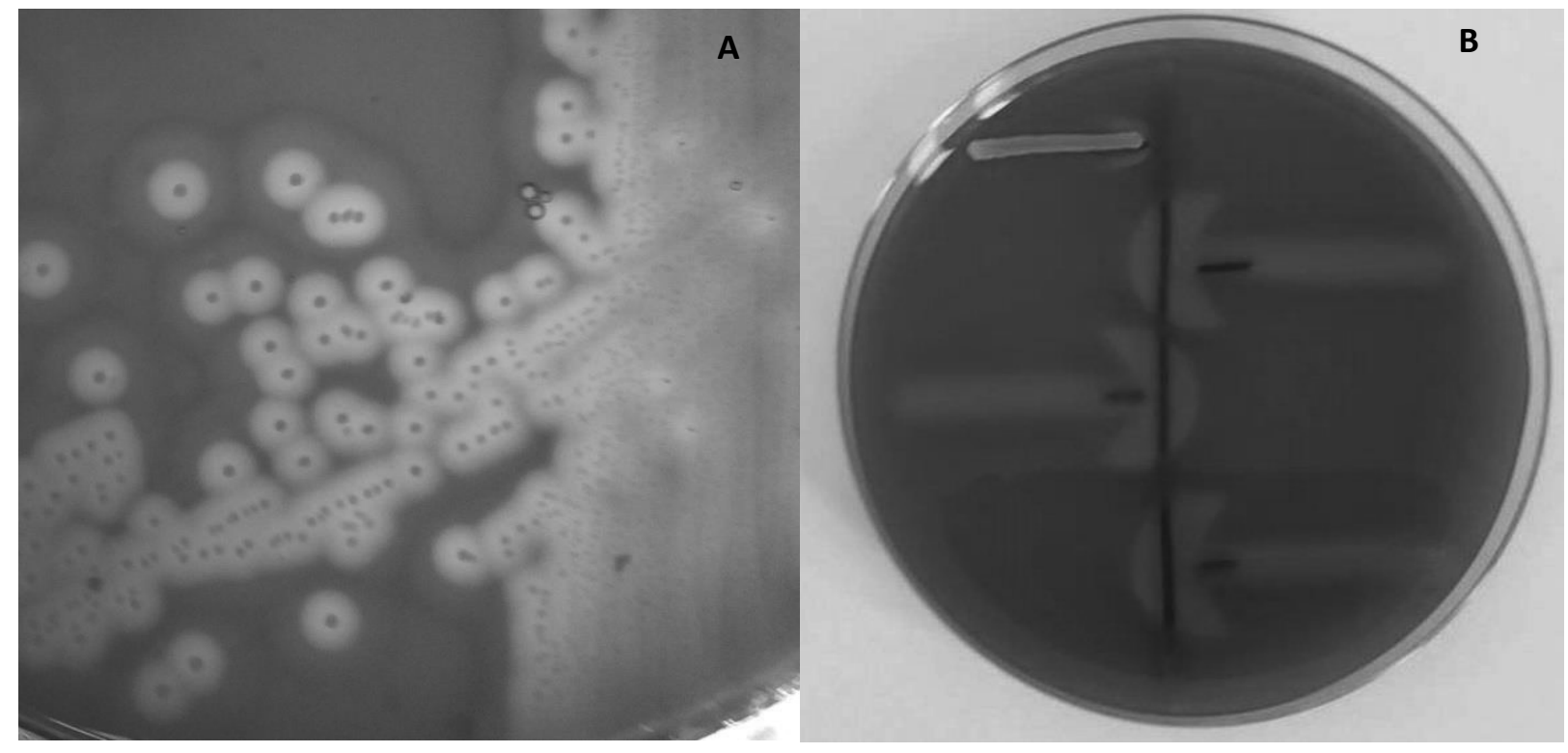

Figure 1. Characteristic colonies of $C$. perfringens on blood agar surrounded by zone of double haemolysis (A); Positive reverse CAMP test: Str. agalactiae ATCC 13813 (vertical line),

Staphylococcus aureus ATCC 25923 (positive control, upper left horizontal line) and C. perfringens isolates $(B)$ 
Table 1.

Target toxin genes, primer sequences and length of amplification products of $C$. perfringens in multiplex PCR (Baums et al., 2004).

\begin{tabular}{|c|c|c|c|}
\hline $\begin{array}{l}\text { Toxin } \\
\text { gene }\end{array}$ & Primers & Sequence $\left(5^{\circ}-3^{\prime}\right)$ & $\begin{array}{c}\text { Length of } \\
\text { amplification } \\
\text { products (bp) }\end{array}$ \\
\hline cpa & $\begin{array}{l}\text { CPA5L } \\
\text { CPA5R }\end{array}$ & $\begin{array}{l}\text { AGTCTACGCTTGGGATGGAA } \\
\text { TTTCCTGGGTTGTCCATTTC }\end{array}$ & 900 \\
\hline$c p b$ & $\begin{array}{l}\text { CPBL } \\
\text { CPBR }\end{array}$ & $\begin{array}{l}\text { TCCTTTCTTG,AGGGAGGATAAA } \\
\text { TGAACCTCCTATTTTGTATCCCA }\end{array}$ & 611 \\
\hline cpe & $\begin{array}{l}\text { CPEL } \\
\text { CPER }\end{array}$ & $\begin{array}{c}\text { GGGGAACCCTCAGTAGTTTCA } \\
\text { ACCAGCTGGATTTGAGTTTAATG }\end{array}$ & 506 \\
\hline etx & $\begin{array}{l}\text { CPETXL } \\
\text { CPETXR }\end{array}$ & $\begin{array}{l}\text { TGGGAACTTCGATACAAGCA } \\
\text { TTAACTCATCTCCCATAACTGCAC }\end{array}$ & 396 \\
\hline iap & $\begin{array}{l}\text { CPIL } \\
\text { CPIR }\end{array}$ & $\begin{array}{c}\text { AAACGCATTAAAGCTCACACC } \\
\text { CTGCATAACCTGGAATGGCT }\end{array}$ & 293 \\
\hline$c p b 2$ & $\begin{array}{l}\text { CPB2L } \\
\text { CPB2R }\end{array}$ & $\begin{array}{l}\text { CAAGCAATTGGGGGAGTTTA } \\
\text { GCAGAATCAGGATTTTGACCA }\end{array}$ & 200 \\
\hline
\end{tabular}

Table 2.

The sources of $C$. perfringens isolates and the results of their toxo-typing

\begin{tabular}{|c|c|c|c|c|}
\hline \multirow{2}{*}{$\begin{array}{l}\text { Sources and sample } \\
\text { numbers }\end{array}$} & \multicolumn{3}{|c|}{ Genotype } & \multirow[t]{2}{*}{ Phenotype } \\
\hline & cpa+ & $c p a+, c p b 2+$ & cpa+, cpe+ & \\
\hline Poultry feed mixture (13) & 10 & 4 & - & $A$ \\
\hline Pig feed mixture (8) & 5 & 4 & - & A \\
\hline Cow feed mixture (7) & 4 & 4 & - & $A$ \\
\hline Sunflower meal (2) & 2 & - & - & $A$ \\
\hline Premix (1) & - & 1 & - & A \\
\hline Cow's organs $(n=1)$ & - & - & 1 & $A$ \\
\hline Total & 21 & 13 & 1 & \\
\hline
\end{tabular}

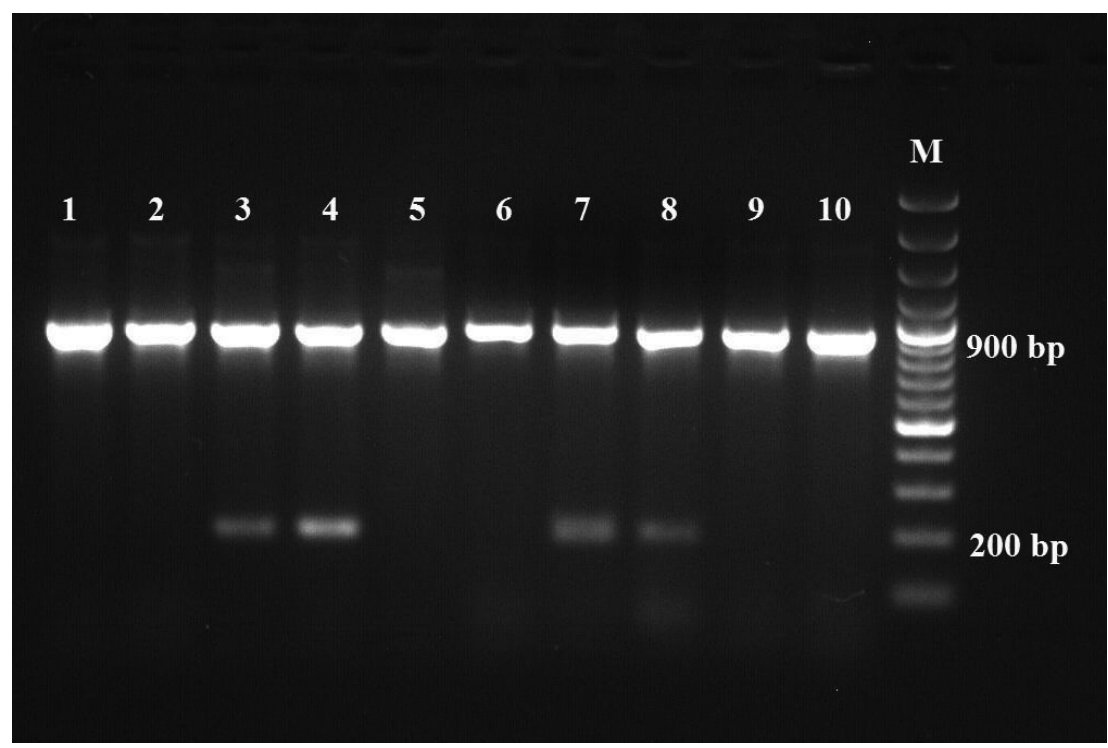

Figure 2. Lane 1 C. perfringens ATCC 13124; lanes 2, 5, 6, 9 and 10: $C$. perfringens isolates type A strains with $\alpha$ toxin (cpa); lanes 3, 4, 7 and 8: C. perfringens type A with $\alpha$ (cpa) and $\beta 2$ toxins (cpb2) 


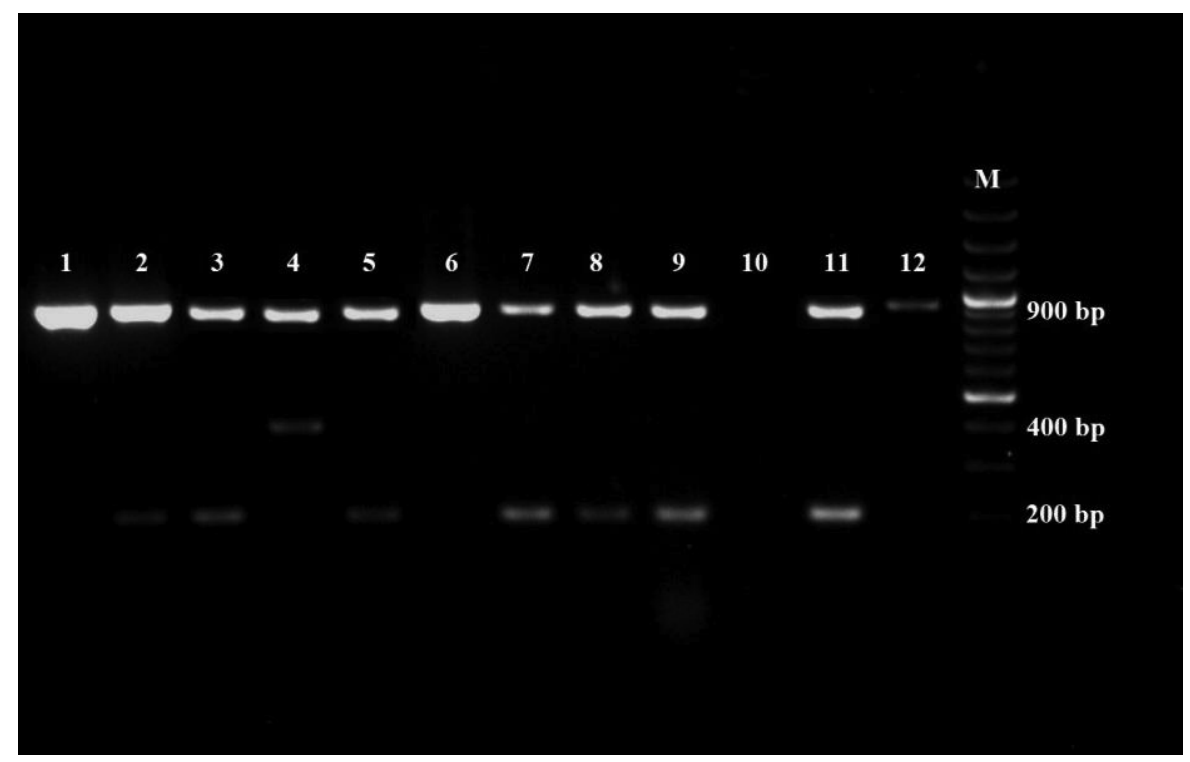

Figure 3. Lane 1 C. perfringens ATCC 13124; lanes 6 and 12: C. perfringens isolates type A strains with $\alpha$ toxin (cpa); lanes 2, 3, 5, 7, 8, 9 and 11: C. perfringens type A with $\alpha$ (cpa) and $\beta 2$ toxins (cpb2); lane 4 C. perfringens type A with enterotoxin (cpe); lane 10 negative control (Clostridium sporogenes ATCC 19404)

Gene for the enterotoxin (cpe) was detected in only one strain, which was isolated from the cow's organs.

Fig. 2. and 3. show agarose gel electrophoresis of the amplicons obtained by multiplex PCR. Lane M - O'Gene Ruler 100 bp DNA marker (Fermentas).

\section{DISCUSSION}

C. perfringens is notorious for being one of the common contaminants of various foodstuffs, which was also proven in this research conducted on several types of animal feed (Kanakaraj et al., 1998; Casagrande et al., 2013; Kukier et al., 2013; Tessary et al., 2014; Udhayavel et al., 2017). In this study, all C. perfringens isolates $(n=34)$ were identified as type $A$ and $\beta 2$-toxinogenic type $A$ strains, possessing only the cpa $(n=21)$, or both the cpa and the cpb2 genes $(n=13)$, respectively. There are numerous data of the widespread presence of these. Type A was the most prevalent toxo-type in feed samples, domestic animal intestines and environmental samples (Wojdat 2006; Kanakaraj et al., 1998; Kukier et al., 2010; Mueller-Spitz et al., 2010).

For example, 174 C. perfringens isolates from environ-mental sources and sewage were identified as type A (Mueller-Spitz et al., 2010) and $53.3 \%$ of isolates from poultry feed belonged to type $A$ and $42 \%$ to type A subtype $\beta-2$ (Kukier et al., 2010). In $96 \%$ faecal samples from poultry fed on these mixtures $C$. perfringens type $A$ was isolated and in $4 \% \beta-2$ type $A$; all samples were taken from chickens and poultry which did not show any signs of diseases.

In Poland 334 C. perfringens isolates from animal feed stuffs were processed with multiplex PCR to detect six genes coding for toxins. Most of the isolates, $50 \%$, possessed genes coding for both $\alpha$ and $\beta 2$ toxins, whilst the gene responsible for $\alpha$ toxin only was detected in $46.4 \%$ isolates, which means that the vast majority of the strains were C. perfringens type A. C. perfringens types $\mathrm{E}, \mathrm{C}$, (including the one with a $\beta 2$ toxin gene) and type $D$ capable of producing $\beta 2$ toxin made up for less than $4 \%$ of the isolates in total (each present in less than $1 \%$ of the isolates), whilst C. perfringens type $B$ was not detected (Wojdat et al., 2006).

C. perfringens type $\mathrm{A}$ is the most common of all C. perfringens types, and is part of the normal gut microbiome in humans and animals. Of all major lethal toxins, type A produces only the $\alpha$-toxin, common to all 
C. perfringens toxotypes (Uzal et al., 2010). The $\alpha$-toxin is an enzyme, a phospholipase which hydrolyzes lecithin (Niilo, 1980; Yoo et al., 1997). Because the membranes of the majority mammalian cells are composed of lipoproteins containing lecithin, its destruction leads to necrosis, hemolysis, or even death, depending on the tissue(s) involved. The $\alpha$-toxin is essential for the pathogenesis of gas gangrene and its production is considered a housekeeping capacity of all $C$. perfringens strains. However, the role of this microorganism and its major $\alpha$-toxin in natural intestinal disease remains controversial and poorly documented (Uzal et al., 2010). C. perfringens type $A$ is even considered to be the most confusing organism in respect to its pathogenicity (Niilo, 1980; Ata et al., 2013).

C. perfringens type $A$ has been reported to cause enterotoxemia in sheep and calves, sometimes even leading to sudden deaths. However, most of the data were not proven and based mainly on bacterial isolation and clinical signs, which were unspecific. Alpha toxin is present in the gut content of many clinically healthy animals. Thus, its detection in the intestinal content of affected animals is irrelevant for the diagnosis of the disease (Uzal et al., 2010). In addition, $C$. perfringens type $A$ can be readily isolated from samples taken soon after death, can be grown easily and may mask other bacteria, implying that it had been the only causative agent. Researchers failed to produce acute enterotoxemia in calves and sheep by intraduodenal administration of $C$. perfringens type A. Administered intravenously, the toxin led to death only in relatively large doses applied within a short time, whilst slow application resulted in milder effects, probably due to rapid elimination. In sum, it seems unlikely that $\alpha$-toxin can be produced in the intestines in high quantities and absorbed rapidly enough to result in fatal toxemia (Niilo, 1980).

Alfa-toxin production was believed to be an essential virulence factor in the pathogenesis of both clinical and subclinical necrotic eneteritis (NE) in laying hens and turkeys (Lyhs et al., 2013; Tessari et al., 2014). Recently it was established that only strains producing NetB toxin, a $\beta$ poreforming toxin, are capable of inducing $\mathrm{NE}$ in broiler chickens under specific predisposing conditions (Keyburn et al., 2008; Timbermont et al., 2011; Antonissen et al., 2014; Uzal et al., 2015). High numbers of C. perfringens present in the intestinal tract or inoculated to chickens do not produce NE (Baba et al., 1997; Kukier et al., 2010; Lyhs et al., 2013, Antonissen et al., 2014). Given that $C$. perfringens does not produce enzymes for the synthesis of 13 aminoacids, its growth is limited in the environment with restricted aminoacid contents (Cooper and Songer, 2009; Brynestad and Granum, 2002; Antonissen et al., 2014). The outbreak of the disease is influenced by various non-specific factors contributing to intestinal environment, which favours the growth of C. perfringens, leading to mucosal damage, increased gut permeability and decreased peristaltic movements. The best-known predisposing factor is mucosal damage caused by coccidia (Baba et al., 1997; Williams, 2005; Collier et al., 2008). A variety of factors can contribute to the outbreak of the disease, such as high wheat, barley or fish meal contents in feed (Lyhs et al., 2013), high levels of indigestible, water-soluble, non-starch polysaccharides (Jia et al., 2009), high concentrations of animal proteins (Gholamiandehkordi et al., 2007), animal fat (Knarreborg et al., 2002), programmed alterations in the feeding regime and immunesuppressive agents such as the viruses of chick anaemia, Gumboro disease or Marek's disease (Timbermont et al., 2011), and the Fusarium mycotoxin deoxynivalenol (Antonissen et al., 2014).

One of the difficulties in the understanding of the pathogenesis and diagnosis of enteric disease caused by $C$. perfringens is based on the fact that most of its types can frequently be found in the intestines of healthy animals. Simple isolation of $C$. perfringens is therefore of no use in diagnostic of enteric infections (Uzal et al., 2015). The intestines of birds suffering NE contain large numbers of $C$. perfringens, up to $10^{6}$ or $10^{8} \mathrm{CFU} / \mathrm{g}$ of intestinal contents (Cooper and Songer, 2009), whereas in healthy broilers the counts usually range 
up to $10^{2}$, or $10^{3} \mathrm{CFU} / \mathrm{g}$ (Baba et al., 1997; Kukier et al., 2010). For epizootical analysis of animal diseases caused by $C$. perfringens, strains isolated from affected birds and the feed they had consumed should be compared. First, the toxotype and subtype is to be detected (with PCR), which is followed by the confirmation of identical DNA profiles (with pulsed-field gel electrophoresis) (Kukier et al., 2010). However, additional research may detect some other anaerobes in feed, which may also conduce to diseases. PCR analysis may detect that healthy birds can carry 2-5 genotypes of $C$. perfringens type $A$, contrary to those affected, which are colonized by a single genetic type other than that found in diseased birds (Cooper and Songer, 2009).

The answer to the question whether $C$. perfringens is a general foodborne pathogen is immensely complicated. In its toxigenic behaviour type $A$ can be subdivided into two varieties. The "classical" variety, characterized mainly by $\alpha$-toxin production, is associated with gas gangrene, traumatic infections and the normal intestinal tract. In the beginning, $\alpha$-toxin was considered to play the main role in human food poisoning and enteritis, but another variety of type $A$, which is producing the enterotoxin (CPE), was later determined. The enterotoxin was first isolated in 1970 (Brynestad and Granum, 2002). About $1-5 \%$ of all C. perfringens type A strains can produce it (Miyamoto et al., 2004; Lindström et al., 2011; MuellerSpitz et al., 2010).

Foodborne diseases caused by C. perfringens can only result from strains carrying the cpe gene, which encods for the enterotoxin (Niilo, 1980; Goldner et al., 1986; Xiao et al., 2012) and is located in the bacterial chromosome or on large plasmids (Brynestad and Granum, 2002; Smedley et al., 2004; Miyamoto et al., 2004; Lindström et al., 2011; Kukier et al., 2010). The enterotoxin is a cytotoxic polypeptide which causes fluid and electrolyte loss from the intestinal mucosa. Type $A$ CPE-positive strains also cause several non-foodborne human gastrointestinal diseases, including about $5-10 \%$ of all cases of antibiotic-associated diarrhea (Fre- edman et al., 2016). CPE is produced in the small intestine after ingestion of at least $10^{7} \mathrm{C}$. perfringens cells (Brynestad and Granum, 2002).

Molecular detection of genes encoding for enterotoxins is extremely important in the inspection of animal-derived foodstuffs and is more reliable than conventional enterotoxin detection; they are all intended for the prevention of the entrance of these strains into the food chain (Kanakaraj et al., 1998). In this research, the gene coding for enterotoxin was detected only in one $C$. perfringens strain isolated from a dead cow, but not in the feed mixture which the animal had been fed on. This result implies that animal feed is irrelevant to the entrance of cpe-positive strains of $C$. perfringens to the food chain. Previously, the use of toxin genotyping of $C$. perfringens from swine feed sampled on different farms $(n=60)$ found no isolates positive for cpe (Kanakaraj et al., 1998). In addition, molecular typing of isolates obtained from swine denied that this species was a source of cpe-positive strains of C. perfringens (Kanakaraj et al., 1998).

Gene coding for $\beta-2$ toxin (cpb2) was confirmed in $13 C$. perfringens isolates: in those originating from feed intended for poultry $(n=4)$, pigs $(n=4)$ and cows $(n=4)$, and from a praemix $(n=1)$. This toxotype might be important for the development of enteric diseases in pigs and cattle. A significant correlation (82\%) between $C$. perfringens possessing the $\beta 2$-toxin gene and diarrhoea in piglets was identified, suggesting that $\beta 2$-toxin may play a key role in the pathogenesis of the disease (Garmory et al., 2000). More than $85 \%$ of isolates from cases of porcine enteritis and $91.8 \%$ isolates of newborn pig enetiritis were positive for the $c p b 2$ gene (Bueschel et al., 2003). However, cpb2-positive strains can be found in both healthy and diseased chickens and its presence does not correlate with disease (Keyburn et al., 2008). Pulsed-field gelelectrophoresis performed on $C$. perfringens isolated from turkeys with NE and from healthy birds, in all of them detected $\alpha$-toxin, and in one both $\alpha$ and $\beta 2$ toxins, which indicates that the $\beta 2$ toxin is not an important virulence factor in the development of NE (Lyhs et 
al., 2013). Beta-2 toxin has been associated with porcine, equine and bovine gastroenteritis (Bueschel et al., 2003; Van Immerseel et al., 2004).

In type A strains isolated from various animals, food products and environment the prevalence of the $c p b 2$ gene is high (Bueschel et al., 2003; Garmory, et al. 2000; Mueller-Spitz et al., 2010). The gene is plasmid-borne, at least in some strains (Shimizu et al., 2002), which implies its mobility and the possibility of transfer among strains of $C$. perfringens.

In this research all animal feed samples from which $C$. perfringens was isolated the spore numbers were less than $100 \mathrm{CFU} / \mathrm{g}$. In similar trials the numbers in feeds did not exceed $10^{2} \mathrm{CFU} / \mathrm{g}$ (Kukier et al., 2010) or $10^{3} \mathrm{CFU} / \mathrm{g}$ (Wojdat et al., 2006). Thus, it is reasonable to raise the question why the numbers of $C$. perfringens in feed are to be assessed given that the Regulation orders that feed be condemned if this species is even detected. Estimating the numbers would be sound if maximum allowed numbers per gram had been established. The PCR test ensures the detection of all genes considered to be important virulence factors in C. perfringens-mediated enteritis or enterotoxaemia and thus provides a useful and reliable tool for $C$. perfringens genotyping in routine veterinary diagnostics (Baums et al., 2004). The mPCR assay is recommended for risk assessment of $C$. perfringens toxotypes isolated from animal feed. The obtained results can help to establish microbiological criteria for critical limits of the presence of $C$. perfringens in feed (Wojdat et al., 2006).

\section{ACKNOWLEDGEMENTS}

This work was supported by the grant provided by the Ministry of Education, Science and Technological Development of the Republic of Serbia for the Projects Nos. TR 31071 and III 46002.

\section{REFERENCES}

1. Antonissen, G., Van Immerseel, F., Pasmans, F., Ducatelle, R., Haesebrouck, F., Timbermont L., Verlinden, M., Paul, G., Janssens, J., Eeckhaut, V., Eeckhout, M., De Saeger, S., Hessenberger,S., Martel, A., Croubels, S. (2014).
The mycotoxin deoxynivalenol predisposes for the development of Clostridium perfringensinduced necrotic enteritis in broiler chickens. PLoS ONE, 9 (9), e108775. DOI:10.1371/journal.pone.0108775.

2. Ata, N., Khairy, E.A., Dorgham, S.M., Zaki, M.S. (2013). Clostridium perfringens disease. Life Science Journal, 10 (1), 1599-1602.

3. Baba, E., Ikemoto, T., Fukata, T., Sasai, K., Arakawa, A., McDougald, L.R. (1997). Clostridial population and the intestinal lesions in chickens infected with Clostridium perfringens and Eimeria necatrix. Veterinary Microbiology, 54 (3-4), 301-308.

4. Baums, C.G., Schotte, U., Amtsberg, G., Goethe, R. (2004). Diagnostic multiplex PCR for toxin genotyping of Clostridium perfringens isolates. Veterinary Microbiology, 100 (1-2), 1116.

5. Brynestad, S., Granum, P.E. (2002). Clostridium perfringens and foodborne infections. International Journal of Food Microbiology, 74 (3), 195-202.

6. Bueschel, D.M., Jost, B.H., Billington, S.J., Trinh, H.T., Songer, J.G. (2003). Prevalence of $c p b 2$, encoding beta2 toxin, in Clostridium perfringens field isolates: correlation of genotype with phenotype. Veterinary Microbiology, 94 (2), 121-129.

7. Casagrande, M.F., Cardozo, M.V., BeraldoMassoli, M.C., Boarini, L., Longo, F.A., Paulilo, A.C., Schocken-Iturrino, R.P. (2013). Clostridium perfringens in ingredients of poultry feed and control of contamination by chemical treatments. The Journal of Applied Poultry Research, 22 (4), 771-777.

8. Collier, C.T., Hofacre, C.L., Payne, A.M., Anderson, D.B., Kaiser, P., Mackie, R.I., Gaskins, H.R. (2008). Coccidia-induced mucogenesis promotes the onset of necrotic enteritis by supporting Clostridium perfringens growth. Veterinary Immunology and Immunopathology, 122 (1-2), 104-115.

9. Cooper, K.K., and Songer, J.G. (2009). Necrotic enteritis in chickens: A paradigm of enteric infection by Clostridium perfringens type $A$. Anaerobe, 15 (1-2), 55-60.

10. EFSA (2005). Opinion of the Scientific Panel on Biological Hazards on a request from the Commission related to Clostridium spp in foodstuffs. The EFSA Journal, 199, 1-65. Adopted on $\quad 9-10 \quad$ March 2005. (https://efsa.onlinelibrary.wiley.com/doi/epdf/10. 2903/i.efsa.2005.199).

11. Freedman J.C., Shrestha A., McClane B.A. (2016). Clostridium perfringens enterotoxin: Action, genetics, and translational applications. Toxins, 8 (3), 73, DOI:10.3390/toxins8030073.

12. Garmory, H.S., Chanter, N., French, N.P., Bueschel, D., Songer J.G., Titball, R.W. (2000). Occurrence of Clostridium perfringens beta 2toxin amongst animals, determined using genotyping and subtyping PCR assays. Epidemiology and Infection, 124 (1), 61-67. 
13. Gholamiandehkordi, A.R., Timbermont, L., Lanckriet, A., Van Den Broeck, W., Pedersen, K., Dewulf J., Pasmans, F., Haesebrouck, F., Ducatelle, R.,Van Immerseel, F. (2007). Quantification of gut lesions in a subclinical necrotic enteritis model. Avian Pathology, 36 (5), 37582.

14. Goldner, S.B., Solberg, M., Jones, S., Post, L.S. (1986). Enterotoxin synthesis by nonsporulating cultures of Clostridium perfringens. Applied and Environmental Microbiology, 52 (3), 407-412.

15. Hatheway, C.L. (1990). Toxigenic Clostridia. Clinical Microbiology Reviews, 3 (1), 66-98.

16. Jia, W., Slominski, B.A., Bruce, H.L., Blank, G., Crow, G., Jones, O. (2009). Effect of diet type and enzyme addition on growth performance and gut health of broiler chickens during subclinical Clostridium perfringens challenge. Poultry Science, 88 (1), 132-140.

17. Kanakaraj, R., Harris, D.L., Songer, J.G., Bosworth, B. (1998). Multiplex PCR assay for detection of Clostridium perfringens in feces and intestinal contents of pigs and in swine feed. Veterinary Microbiology, 63 (1), 29-38.

18. Keyburn, A.L., Boyce, J.D., Vaz, P., Bannam, T.L., Ford, M.E., Parker, D., Di Rubbo, A., Rood, J.I., Moore, R.J. (2008). NetB, a new toxin that is associated with avian necrotic enteritis caused by Clostridium perfringens. PLoS Pathogens, 4, e26, DOI:10.1371/journal.ppat.0040026.

19. Knarreborg, A., Simon, M.A., Engberg, R.M., Jensen, B.B., Tannock, G.W. (2002). Effects of dietary fat source and subtherapeutic levels of antibiotic on the bacterial community in the ileum of broiler chickens at various ages. Applied and Environmental Microbiology, 68 (12), 5918-5924.

20. Kukier, E., Goldsztejn, M., Kwiatek, K. (2010). Epidemiological investigation of animal diseases caused by Clostridium perfringens strains isolated from feedingstuffs. Krmiva, 52 (6), 339343.

21. Kukier, E., Goldsztejn, M., Grenda, T., Kwiatek, K., Bocian, L. (2013). Microbiological quality of feed materials used between 2009 and 2012 in Poland. Bulletin of the Veterinary Institute in Pulawy, 57 (4), 535-543.

22. Lindström, M., Heikinheimo, A., Lahti, P., Korkeala, H. (2011). Novel insights into the epidemiology of Clostridium perfringens type $A$ food poisoning. Food Microbiology, 28 (2), 192-198.

23. Lyhs, U., Perko-Mäkelä, P., Kallio, H., Brockmann, A., Heinikainen, S., Tuuri, H., Pedersen, K. (2013). Characterization of Clostridium perfringens isolates from healthy turkeys and from turkeys with necrotic enteritis. Poultry Science, 92 (7), 1750-1757.

24. Miyamoto, K., Qiyi Wen, Q., Bruce, A. McClane, B.A. (2004). Multiplex PCR genotyping assay that distinguishes between isolates of Clostridium perfringens type A carrying a chro- mosomal enterotoxin gene (cpe) locus, a plasmid cpe locus with an IS1470-like sequence, or a plasmid cpe locus with an IS1151 sequence. Journal of Clinical Microbiology, 42 (4), 15521558.

25. Mueller-Spitz, S.R., Stewart, L.B., Klump, J.V., McLellan, S.L. (2010). Freshwater suspended sediments and sewage are reservoirs for enterotoxin-positive Clostridium perfringens. Applied and Environmental Microbiology, 76 (16), 5556-5562.

26. Niilo, L. (1980). Clostridium perfringens in animal disease: a review of current knowledge. The Canadian Veterinary Journal, 21 (5), 141148.

27. Sawires, Y.S., Songer, J.G. (2006). Clostridium perfringens: Insight into virulence evolution and population structure. Anaerobe, 12 (1), 23-43.

28. Shimizu, T., Ohtani, K., Hirakawa, H., Ohshima, K., Yamashita, A., Shiba, T., Ogasawara, N., Hattori, M., Kuhara, S., Hayashi, H. (2002). Complete genome sequence of Clostridium perfringens, an anaerobic flesh-eater. Proceedings of the National Academy of Sciences of the United States of America, 99 (2), 996-1001.

29. Smedley, J.G., Fisher, D.J., Sayeed, S., Chakrabarti, G., McClane, B.A. (2004). The enteric toxins of Clostridium perfringens. Reviews of Physiology, Biochemistry and Pharmacology, 152, 183-204.

30. Songer, J.G. (1996). Clostridial enteric diseases of domestic animals. Clinical Microbiology Reviews, 9 (2), 216-234.

31. SRPS ISO 7937: Horizontalna metoda za određivanje broja Clostridium perfringens Tehnika brojanja kolonija (Horizontal method for enumeration of Clostridium perfringens-Coloniycount technique), Institut za standardizaciju Srbije, 2010.

32. Tessari, E.N.C., Cardoso, A.L.P., Kanashiro, A.M.I., Stoppa, G.F.Z., Luciano, R.L., deCastro, A.G.M. (2014). Analysis of the presence of Clostridium perfringens in feed and raw material used in poultry production. Food and Nutrition Sciences, 5 (7), 614-617.

33. Timbermont, L., Haesebrouck, F., Ducatelle, R., Van Immerseel, F. (2011). Necrotic enteritis in broilers: an updated review on the pathogenesis. Avian Pathology, 40 (4), 341-347.

34. Udhayavel, S., Ramasamy, G.T., Gowthaman, V., Malmarugan, S., Senthilvel K. (2017). Occurrence of Clostridium perfringens contamination in poultry feed ingredients: Isolation, identification and its antibiotic sensitivity pattern. Animal Nutrition, 3 (3), 309-312.

35. Uzal, F.A., McClane, B.A., Cheung, J.K., Theoret, J., Garcia, J.P., Moore, R.J., Rood, J.I. (2015). Animal models to study the pathogenesis of human and animal Clostridium perfringens infections. Veterinary Microbiology, 179 (1-2), 23-33.

36. Uzal, F.A., Freedman, J.C., Shrestha, A., Theoret, J.R., Garcia, J., Awad M.M., Adams, V., Moore, R.J., Rood, J.I., McClane, B.A. (2014). Towards an understanding of the role of Clos- 
tridium perfringens toxins in human and animal disease. Future Microbiology, 9 (3), 361-377.

37. Uzal, F.A., Vidal, J.E., McClane, B.A., Gurjar, A.A. (2010). Clostridium perfringens toxins involved in Mammalian veterinary diseases. The Open Toxinology Journal, 2, 24-42.

38. Xiao, Y., Wagendorp, A., Moezelaar, R., Abee T., Wells-Bennik M.H. (2012). A wide variety of Clostridium perfringens type A food-borne isolates that carry a chromosomal cpe gene belong to one multilocus sequence typing cluster. Applied and Environmental Microbiology, 78 (19), 7060-7068.

39. Van Immerseel, F., De Buck, J., Pasmans, F., Huyghebaert, G., Haesebrouck, F., Ducatelle, R. (2004). Clostridium perfringens in poultry: an emerging threat for animal and public health. Avian Pathology, 33 (6), 537-549.

40. Williams, R.B. (2005). Intercurrent coccidiosis and necrotic enteritis of chickens: rational, integrated disease management by maintenance of gut integrity. Avian Pathology, 34 (3), 159-180.

41. Wojdat, E., Kwiatek, K., Kozak, M. (2006). Occurrence and characterization of some Clostridium species isolated from animal feedingstuffs. Bulletin of the Veterinary Institute in Pulawy, 50 (1), 63-67.

42. Yoo, H.S., Lee, S.U., Park, K.Y., Park, Y.H. (1997). Molecular typing and epidemiological sur-vey of prevalence of Clostridium perfringens types by multiplex PCR. Journal of Clinical Microbiology, 35 (1), 228-232.

\title{
ТОКСИН ГЕНОТИПИЗАЦИЈА СОЈЕВА Clostridium perfringens ИЗОЛОВАНИХ ИЗ ХРАНЕ ЗА ЖИВОТИҢЕ И ЊИХОВ ЗНАЧАЈ У ЕТИОЛОГИЈИ ЕНТЕРОТОКСЕМИЈА ДОМАЋИХ ЖИВОТИҢА
}

\author{
Дубравка С. Миланов ${ }^{1}$, Тамаш Р. Петровић ${ }^{1}$, Далибор С. Тодоровић ${ }^{1}$, \\ Невенка Р. Алексић ${ }^{2}$, Ивана С. Чабаркапа ${ }^{3}$ \\ ${ }^{1}$ Научни институт за ветеринарство „Нови Сад“, 21000 Нови Сад, Руменачки пут 20, Србија \\ 2 Универзитет у Београду, Факултет ветеринарске медицине, 11000 Београд, Булевар \\ ослобођења 18, Србија \\ ${ }^{3}$ Универзитет у Новом Саду, Научни институт за прехрамбене технологије у Новом Саду, 21000 \\ Нови Сад, Булевар цара Лазара 1, Србија
}

Сажетак: Clostridium perfringens је Грам-позитивна, анаеробна, спорулишућа, штапићаста бактерија, убиквитарно распрострањена у природи. Код различитих сојева С. Perfringens, до данас, идентификовано је око 17 врста токсина. C. perfringens је узрочни агенс различитих обољења (синдрома), али су цревне инфрекције/интоксикације најчешће и од највећег значаја за здравље фрармски гајених животиња. У овом раду приказујемо резултате испитивања сојева $C$. perfringens пореклом из хране за животиње $(n=34)$ и једног изолата из органа краве угинуле са знацима ентеротоксемије на присуство гена: $c p a, c p b, c p b 2$, cpe, etx и іар применом мултиплекс PCR технике. Сви сојеви C. perfringens изоловани из хране за животиње, идентификовани су као тип А који поседује само сра ген $(n=21)$ или тип А који продукује $\beta 2$-токсин, односно има сра и $c p b 2$ гене $(n=13)$. У раду дискутујемо о улози алфра $(\alpha)$ и бета-2 (32) токсина у патогенези ентеротоксемија домаћих животиња, као и актуелном законском пропису по којем ова врста бактерије не сме бити присутна у храни за животиње. Примена PCR технике у свакодневној пракси омогућила би токсин-генотипизацију сојева C. perfringens, а тиме и реалне основе за успостављање граничних дозвољених вредности за ову врсту бактерије у храни за животиње.

Кључне речи: Clostridium perfringens, токсин генотипизација, храна за животиње, мултиплекс PCR техника, сра ген, сpb2 ген

Received: 17 May 2018

Received in revised form: 6 June 2018

Accepted: 9 June 2018 